\title{
Pathogenic mechanisms of neurodegeneration based on the phenotypic expression of progressive forms of immune-mediated neurologic disease
}

This article was published in the following Dove Press journal:

Degenerative Neurological and Neuromuscular Disease

4 December 2012

Number of times this article has been viewed

\author{
Michael C Levin ${ }^{1-3}$ \\ Sangmin Lee ${ }^{1,2}$ \\ Lidia A Gardner ${ }^{1,2}$ \\ Yoojin Shin ${ }^{1,2}$ \\ Joshua N Douglas ${ }^{1,3}$ \\ Chassidy J Groover ${ }^{1,2}$ \\ 'Veterans Administration Medical \\ Center, Memphis, TN, USA; \\ ${ }^{2}$ Departments of Neurology, \\ ${ }^{3}$ Neuroscience, University of \\ Tennessee Health Science Center, \\ Memphis, TN, USA
}

\begin{abstract}
Considering there are no treatments for progressive forms of multiple sclerosis (MS), a comprehensive understanding of the role of neurodegeneration in the pathogenesis of MS should lead to novel therapeutic strategies to treat it. Many studies have implicated viral triggers as a cause of MS, yet no single virus has been exclusively shown to cause MS. Given this, human and animal viral models of MS are used to study its pathogenesis. One example is human T-lymphotropic virus type 1-associated myelopathy/tropical spastic paraparesis (HAM/TSP). Importantly, HAM/TSP is similar clinically, pathologically, and immunologically to progressive MS. Interestingly, both MS and HAM/TSP patients were found to make antibodies to heterogeneous nuclear ribonucleoprotein (hnRNP) A1, an RNA-binding protein overexpressed in neurons. Anti-hnRNP A1 antibodies reduced neuronal firing and caused neurodegeneration in neuronal cell lines, suggesting the autoantibodies are pathogenic. Further, microarray analyses of neurons exposed to anti-hnRNP A1 antibodies revealed novel pathways of neurodegeneration related to alterations of RNA levels of the spinal paraplegia genes (SPGs). Mutations in SPGs cause hereditary spastic paraparesis, genetic disorders clinically indistinguishable from progressive MS and HAM/TSP. Thus, there is a strong association between involvement of SPGs in neurodegeneration and the clinical phenotype of progressive MS and HAM/TSP patients, who commonly develop spastic paraparesis. Taken together, these data begin to clarify mechanisms of neurodegeneration related to the clinical presentation of patients with chronic immune-mediated neurological disease of the central nervous system, which will give insights into the design of novel therapies to treat these neurological diseases.
\end{abstract}

Keywords: human T-lymphotropic virus type 1 (HTLV-1), multiple sclerosis, neurodegeneration, heterogeneous nuclear ribonucleoprotein A1 (hnRNP A1), autoimmunity, spastic paraparesis, RNA-binding protein

\section{Clinical phenotype of progressive neurodegenerative diseases}

Multiple sclerosis (MS) is the most common human demyelinating disease of the central nervous system (CNS), affecting as much as $0.2 \%$ of the population in high-prevalence areas. ${ }^{1}$ MS most frequently affects middle-aged people, and there are an estimated 2 million cases worldwide, ${ }^{1}$ of which 400,000 are in the United States. ${ }^{2}$ Initially, two-thirds of patients develop relapsing-remitting MS (RRMS), in which neurological symptoms occur followed by complete or incomplete recovery. $1,3,4$ Over time, a significant proportion (up to $90 \%$ within 25 years $^{2}$ ) of these patients may 
develop neurological deterioration independent of relapses and thus develop "secondary progressive MS" (SPMS). ${ }^{1,3,4}$ Approximately $15 \%$ of people develop primary progressive MS (PPMS), in which neurological symptoms progress over time without relapses. ${ }^{1,3,4}$ Thus, the majority of patients develop progressive forms of MS during their lifetime. ${ }^{1,2,4}$ Progression in individual patients is highly variable, and may be related to whether patients have plaques in the brain, spinal cord, or both. ${ }^{5,6}$ Common symptoms of progressive forms of MS include spastic paraparesis, sensory dysfunction including neuropathic pain, and urinary disturbance. ${ }^{7}$

Despite decades of research, the etiology of MS remains elusive. Evidence indicates that exposure to an environmental agent (such as a virus) in a genetically susceptible person results in a series of immunological events that lead to neurological damage. Importantly, a number of hypotheses have attempted to link exposure to environmental agents with stimulation of the immune response, which in turn leads to CNS damage. One example is molecular mimicry. The challenge in studying molecular mimicry in MS is that an infectious agent has not unequivocally been shown to cause it, although data suggest Chlamydia pneumoniae, human herpes virus 6, or Epstein-Barr virus may play a role. ${ }^{8-10}$ To address this, we use human T-lymphotropic virus type 1 (HTLV-1)associated myelopathy/tropical spastic paraparesis (HAM/ TSP) as a model to study molecular mimicry in autoimmune diseases of the CNS. ${ }^{11-15}$ HAM/TSP is caused by HTLV-1, which allows for the direct comparison of the infecting agent with host antigens. ${ }^{16-24}$ Importantly, HAM/TSP patients are similar clinically, pathologically, and immunologically to people with progressive MS. In fact, many HAM/TSP patients were initially diagnosed with PPMS. ${ }^{11-13,19,20,25,26}$

In addition to HAM/TSP, progressive forms of MS are clinically and pathologically similar to the hereditary spastic paraplegias (HSPs) (Table 1). ${ }^{7,27,28}$ The HSPs are a clinically and genetically diverse group of diseases, which like progressive MS and HAM/TSP are characterized by spastic paraparesis, urinary symptoms, and posterior column dysfunction. HSPs are caused by mutations in the spinal paraplegia genes (SPGs). The predominant manifestation of "pure or uncomplicated" HSP is spastic paraparesis. Patients with "complicated" HSPs develop spastic paraparesis concurrent with other neurologic abnormalities, such as ataxia, optic atrophy, peripheral neuropathy, retinopathy, and dementia. ${ }^{27,28} \mathrm{MS}$ and HAM/TSP patients also exhibit some of these symptoms. ${ }^{21-24}$ Pathologically, progressive MS, HAM/TSP, and HSP are characterized by damage to and neurodegeneration of the long tracts of the CNS, including the
Table I Clinical and pathological features of progressive MS, HAM/TSP, and HSP

\section{Clinical}

- Spastic paraparesis

- Sensory dysfunction

- Urinary disturbance

Pathological

- Axonal damage/neurodegeneration

- Corticospinal motor system

- Posterior column/medial lemniscal sensory system

- Spinal cord atrophy

Genetic contribution

- MS: HLA DRBI*I50I/DQBI*602

- HAM/TSP: HLA DRBI*0IOI

- HSP: autosomal dominant/recessive, X-linked

Etiology

- MS: autoimmune (viruses considered)

- HAM/TSP: HTLV-I infection associated with autoimmunity

- HSP: mutations of SPGs

Abbreviations: MS, multiple sclerosis; HAM/TSP, human T-lymphotropic virus type I (HTLV-I)-associated myelopathy/tropical spastic paraparesis; HSP, hereditary spastic paraparesis; SPGs, spinal paraplegia genes; HLA, human leukocyte antigen.

corticospinal tracts and posterior column/medial lemniscal sensory system (Table 1). 7,11,27-33

\section{Contribution of neurodegeneration to the pathogenesis of immune- mediated neurological diseases}

Over the past several years, there has been a major shift in thinking about the pathogenesis of progressive forms of MS. ${ }^{1,34-47}$ Prevailing hypotheses suggested that progressive disease and disability were related to the location and volume of MS white-matter plaques (the "plaque-centric" viewpoint), and that neurodegeneration was present only in the latter stages of progressive MS. There is now evidence that neurodegeneration is present in all stages of the disease. ${ }^{34,42,48,49}$ In addition, neurodegeneration in progressive forms of MS is not related to white-matter plaques or their location, but rather correlates with gray matter and cortical pathology. 2,34,35,48,50-55 Brain magnetic resonance imaging data support the concept that gray-matter disease and neurodegeneration is a more sensitive marker of progression than white-matter disease. ${ }^{53-55}$ For example, gray-matter atrophy is increased when comparing SPMS patients to controls. ${ }^{53}$ In addition, there was significantly greater gray-matter than white-matter atrophy when comparing SPMS to other forms of MS, and it was gray-matter atrophy that correlated with disability. ${ }^{54}$ Pathologically, cortical demyelination has been shown to contribute significantly to the pathogenesis of MS. 2,34,35,48,50-55 Inflammatory cells and neurodegeneration are present in all stages of MS. However, the type and quantity of inflammatory 
cells and the extent of neurodegeneration are related to MS subtype. For example, in early forms of MS (acute and RRMS), T cells and B cells predominate and correlate with demyelination (plaque location) and neuronal injury, as detected by amyloid precursor protein (APP) staining. ${ }^{36,48}$ In progressive forms of the disease, the inflammatory response is more diffuse (involving CNS parenchyma and meninges) and immunoglobulin $\mathrm{G}$ ( $\mathrm{IgG}$ )-positive plasma cells predominate. ${ }^{48}$ Importantly, B-cell follicle-like structures present in the meninges in SPMS are associated with cortical pathology such as subpial cortical demyelination and atrophy. ${ }^{56,57}$ Also, there is neuronal loss and apoptosis within the motor cortex, particularly in motor pyramidal neurons in layers III and V, which contain the cells of origin of the corticospinal tract. ${ }^{57}$ This is particularly relevant, because in progressive MS patients spastic paraparesis predominates and there is a strong clinical correlation between axonal damage and neurological disability related to the long tracts of the CNS. ${ }^{1}$ For example, analysis of the corticospinal tract and posterior columns in the spinal cord of MS patients showed a significant reduction of nerve-fiber density independent of cerebral plaque location, which correlated strongly with progression. ${ }^{32,58-61}$

The neuropathology of the spinal cord in HAM/TSP closely resembles that seen in progressive forms of MS, and forms the basis for hypotheses related to the pathogenesis of viral-induced, immune-mediated neurological disease. Like MS, the corticospinal tract and posterior columns are preferentially damaged and demonstrate axonal dystrophy and demyelination..$^{20,30,33,62,63}$ In addition, there is increased APP expression indicative of neurodegeneration within the corticospinal tract. ${ }^{29}$ In both HAM/TSP and MS, magnetic resonance images show spinal cord atrophy. ${ }^{64,65}$ There is blood-brain barrier breakdown and infiltration of the CNS with inflammatory cells, which localize predominantly to the thoracic spinal cord, where a majority of cells concentrate in the lateral (inclusive of the corticospinal tract) and posterior columns..$^{20,30,33,62,63}$ These areas also correlate with relatively low blood flow within the spinal cord parenchyma. ${ }^{33} \mathrm{CD} 4^{+}$ and $\mathrm{CD}^{+} \mathrm{T}$ lymphocytes as well as $\mathrm{B}$ cells and natural killer cells have been localized to the spinal cord, and their ratios are related to disease chronicity. ${ }^{19,66}$ Some $\mathrm{CD}^{+}$cells costained with $\mathrm{T}$ cells restricted intracellular antigen 1 , a marker of cytotoxic T cells. ${ }^{33,66}$ Importantly, both HTLV-1 tax provirus and RNA were localized to infiltrating T cells in the spinal cord. ${ }^{67,68}$ There is little evidence of direct infection of neural elements with HTLV-1. Thus, data indicate that immune-mediated mechanisms contribute to the pathogenesis of HAM/TSP. ${ }^{12,13,20,22,24,69-73}$ For example, HAM/TSP patients make immune responses to a number of viral targets including HTLV-1 tax, env, and gag that separates them from control populations. ${ }^{74-77}$ Immunologically, HAM/TSP patients develop $\mathrm{CD}^{+}$, human leukocyte antigen (HLA)-2-restricted cytotoxic $\mathrm{T}$ lymphocytes (CTLs) specific for tax and CD4 ${ }^{+}$ responses to both tax and env that are thought to contribute to disease. ${ }^{74,75,78}$ In contrast, other studies suggest that tax-specific CTLs are protective rather than pathogenic. ${ }^{74,79}$ In addition, CTLs to the newly discovered HTLV-1 basic leucine zipper factor appear to have a protective influence for the development of HAM/TSP. ${ }^{80}$ Interestingly, CD $8^{+}$lymphocytes also play an important role in the pathogenesis of MS. ${ }^{81}$ For example, MS patients have elevated cytotoxic responses by interleukin-15-exposed $\mathrm{CD}^{+}$lymphocytes and cytotoxic $\mathrm{C} 8^{+}$ lymphocytes are present in MS plaques. ${ }^{81,82}$ In HAM/TSP, other inflammatory cells might also contribute to its pathogenesis including natural killer cells and interferon- $\gamma$-secreting Foxp3-CD ${ }^{+} \mathrm{CD} 25^{+} \mathrm{CCR} 4^{+} \mathrm{T}$ cells..$^{23,83,84}$ Interestingly, the HLA class 2 gene $H L A-D R B 1 * 0101$ increased HTLV-1 viral load (blood and spinal fluid) and elevated HTLV-1 antibody titers were found to increase the risk of HAM/TSP. ${ }^{20,74,79,85-87}$ Elevated levels of proinflammatory cytokines such as tumor necrosis factor (TNF)- $\alpha$ and interferon- $\gamma$ are also associated with HAM/TSP, as are interferon-stimulated genes such as STAT1, STAT2, TAP1, and CXCL10. ${ }^{22,88,89}$ Taken together, these data are closely related pathologically and immunologically to MS, and suggest that immune-mediated mechanisms contribute to the pathogenesis of both MS and HAM/TSP.

\section{Mechanisms of neurodegeneration in MS are similar to other neurodegenerative diseases}

The mechanisms underlying neurodegeneration in MS are an area of intense investigation and remain an open question. There is evidence that neurodegeneration might result from lack of trophic support from myelin, ${ }^{41}$ abnormal ion- and sodium-channel expression on axons, ${ }^{1,34,90}$ calcium accumulation in damaged axons, or Wallerian degeneration..$^{34,91}$ Inflammatory cytokines may also play a role. ${ }^{34}$ Several studies have shown that mitochondrial injury and associated oxidative damage, production of reactive oxygen species, and induction of apoptosis contribute to axonal injury. ${ }^{42,92-94}$ Other studies implicate increased energy demands of demyelinating axons and the relative reduction of axonal adenosine triphosphate (ATP) production, which results in a state of "virtual hypoxia." "91,95 
Several studies have demonstrated axonal changes in association with increased APP levels. ${ }^{42,96}$ Importantly, APP accumulation develops in the setting of abnormal fast axonal transport and has been shown not only to accumulate in damaged axons in MS brains ${ }^{48,97}$ but is also an early marker of axonopathy related to impaired axonal transport in Alzheimer's disease. ${ }^{98}$ Notably, increased APP expression is also present within the corticospinal tracts of HAM/TSP patients. ${ }^{29,33}$ Abnormal axonal transport results in neurodegeneration in a number of neurodegenerative diseases. ${ }^{99}$ This is particularly evident in the HSPs. For example, some HSP genes, such as spinal paraplegia gene 4 (SPG4 - spastin), SPG7 (paraplegin), and SPG20 (spartin), have all been shown to contribute to axonal transport. $27,28,99-102$

In addition to these mechanisms, recent studies have implicated RNA-binding proteins (RBPs) and their function in RNA metabolism (ie, transport, stability, translation) as major contributors to abnormal neuronal function and neurodegeneration in amyotrophic lateral sclerosis, spinal muscle atrophy, and dementia. ${ }^{103,104}$ For example, the RBP TAR DNA-binding protein 43 has been identified as a major contributor to amyotrophic lateral sclerosis and frontotemporal dementia. ${ }^{105,106}$ Also, RNA metabolism related to fragile $\mathrm{X}$ mental retardation protein appears to contribute to the pathogenesis of fragile $\mathrm{X}$ syndrome and fragile X syndrome-associated tremor/ataxia. ${ }^{103}$ Further, patients with paraneoplastic neurologic syndromes develop antibodies to RBPs, such as $\mathrm{Hu}$ and Nova. ${ }^{103,107,108}$ Taken together, these data show that neurodegeneration in MS involves mechanisms that are also present in other neurodegenerative diseases.

\section{Antibodies as contributors to neurodegeneration and the pathogenesis of MS}

In addition to $\mathrm{T}$ cells, recent studies have emphasized the role of humoral autoimmunity in the pathogenesis of MS. ${ }^{47,109,110}$ Clinically, intrathecal IgG and oligoclonal bands are a hallmark of MS. ${ }^{109,110}$ Some types of MS show Ig and complement deposition in MS lesions, and some MS patients exhibit a therapeutic response to plasma exchange or B-cell depletion with anti-CD20 antibodies. ${ }^{11-117}$

The humoral immune response may be particularly important when studying neurodegeneration. , $^{1,37-41,118}$ For example, patients with progressive disease are more likely to have B-cell follicle-like structures in the cerebral meninges..$^{56,57,110,117}$ IgG-containing plasma cells are found in the meninges and throughout the brain in MS patients, and persist in progressive forms of MS when T cells and B cells diminish to control levels. ${ }^{48,117}$ Importantly, studies also show that antibodies to neurons and axons contribute to the pathogenesis of neurodegeneration in MS. ${ }^{119,120} \mathrm{In}$ one study, MS patients were found to make antibodies to neurofascin. ${ }^{19,120}$ The autoantibodies reacted to both neurofascin 186 (a neuronal protein located on axons at the nodes of Ranvier) and neurofascin 155, an oligodendrocyte protein. ${ }^{119,120}$ Application of these antibodies to hippocampal slice cultures inhibited axonal conduction. ${ }^{120}$ Following induction of experimental allergic encephalomyelitis with myelin oligodendrocyte glycoprotein-specific $\mathrm{T}$ cells, the addition of antineurofascin antibodies augmented disease. ${ }^{120}$ The antibodies bound to the nodes of Ranvier, resulting in complement deposition and axonal injury. Taken together, these data indicate antibodies that target neuronal antigens are pathogenic. ${ }^{119,120}$

These data suggest that antibodies to CNS targets other than myelin, such as neurons and axons, may make major contributions to the pathogenesis of MS. For example, studies in MS patients revealed that there were elevated antibodies to the "axolemma-enriched fraction," neurofilament, and gangliosides. ${ }^{121-123}$ Also, Owens et al ${ }^{109}$ tested recombinant monoclonal antibodies derived from the light-variable region sequences of plasma and B-cell clones isolated from the cerebrospinal fluid (CSF) of MS patients for immunoreactivity to myelin antigens. Remarkably, none of the recombinant antibodies reacted with myelin basic protein, proteolipid protein, or myelin oligodendrocyte glycoprotein. ${ }^{109}$ These data suggest the myelin compartment may not always be a target for a pathogenic humoral response in MS patients and that other autoantigens might be important. For example, a recent study showed that autoantibodies to the potassium channel KIR4.1, a glial protein, might contribute to the pathogenesis of MS. ${ }^{124,125}$

\section{A potential role for antibodies to the RBP hnRNP Al in the pathogenesis of neurodegeneration in MS and HAM/TSP}

Data generated in our lab also indicate that antibodies to the nonmyelin compartment, specifically neurons, may contribute to the pathogenesis of MS and HAM/TSP. ${ }^{11-14,126-129}$ Initially, 
using neuronal proteins purified from human brain, $\operatorname{IgG}$ isolated from HAM/TSP patients was found to immunoreact with a $33 \mathrm{kDa}$ protein by Western blot. ${ }^{126}$ Subsequently, the protein was identified as heterogeneous nuclear ribonuclear protein A1 (hnRNP A1). ${ }^{14}$ hnRNP A1 is an RBP that has multiple functions, including mRNA nucleocytoplasmic transport, metabolism, and translation. ${ }^{130,131}$ Importantly, HAM/TSP IgG reacted specifically with neurons, but not with proteins isolated from systemic organs. ${ }^{14,132}$ Further, HAM/ TSP IgG reacted preferentially with neurons isolated from human precentral gyrus, including Betz cells, the neuronal cells of origin of the corticospinal tract. ${ }^{14}$ In HAM/TSP brain, in situ IgG localized to the corticospinal tract, pyramidal neurons of the precentral gyrus, and the posterior column/ medial lemniscal sensory system, areas that are commonly damaged in HAM/TSP. ${ }^{30}$ In addition, anti-hnRNP A1 antibodies decreased neuronal firing in ex vivo patch-clamp experiments of rat brain slices. ${ }^{14,133}$ The human epitope of hnRNP A1 recognized by HAM/TSP IgG was mapped to an amino acid sequence (AA 293-GQYFAKPRNQGG-304) contained within M9 (the nuclear transport sequence of hnRNP A1), which is required for its nucleocytoplasmic transport (Figure 1). ${ }^{12,127}$ Importantly, an HTLV-1 tax monoclonal antibody showed cross-reactivity with human neurons and hnRNP A1 indicative of molecular mimicry between the two proteins. ${ }^{12-14,132}$ The cross-reactivity between HTLV-1 tax monoclonal antibodies with a $33 \mathrm{kDa}$ brain-derived protein was replicated independently. ${ }^{134}$ Taken together, these data suggest that HAM/TSP patients develop a highly specific antibody response to neurons that is biologically active and potentially contributory to the pathogenesis of this immune-mediated neurologic disease. $^{12,13}$

Because of similarities between the chronic, progressive nature and pathology of HAM/TSP and progressive forms of MS, we hypothesized that MS patients would also develop antibodies to hnRNP A1. This was found to be the case. ${ }^{11}$ Specifically, IgG isolated from the serum of MS patients immunoreacted with neurons but not systemic organs. In addition, MS IgG immunoreacted with the identical M9 epitope as the HAM/TSP patients (Figure 1). The sera of all $37 \mathrm{MS}$ patients examined were positive for the M9 epitope. In contrast, normal controls and patients with Alzheimer's disease (a control for neurodegenerative disease) showed no immunoreactivity. IgG from the CSF of an MS patient also immunoreacted with the M9 epitope. ${ }^{11}$ Of note, the study group included 49\% RRMS, $27 \%$ SPMS, and 24\% PPMS. Greater than $89 \%$ of patients had clinical evidence of corticospinal dysfunction. ${ }^{11}$ Other groups have confirmed that $\mathrm{IgG}$ isolated from the CSF of HAM/TSP and MS patients immunoreacts with hnRNP A1. ${ }^{135,136}$ We then hypothesized that the anti-hnRNP A1-M9 antibodies might contribute to neurodegeneration. To test this hypothesis, we transfected neurons with anti-M9 and control antibodies and examined them for signs of neurodegeneration and changes in gene expression using microarray. ${ }^{11,137}$ In contrast to control neurons, neurons containing the anti-M9 antibodies showed evidence of neurodegeneration, including positive staining with Fluoro Jade C (a fluorescent marker for degenerating neurons) ${ }^{138}$ and loss of neuronal processes. ${ }^{11}$ Microarray analyses of total RNA extracted from the cells showed that 866 transcripts were significantly altered by the M9-specific antibodies compared to controls. We investigated the functional significance of the gene-expression changes associated with anti-hnRNP A1 M9 antibody transfection of neurons using a dual bioinformatics approach. ${ }^{11}$ First, the 866 genes that were significantly altered by the anti-M9 antibodies were functionally classified by Gene Ontology annotation using the Gene Ontology Tree Machine. Remarkably, the anti-M9 antibodies affected almost all aspects of hnRNP A1's role in nucleocytoplasmic transport and mRNA processing

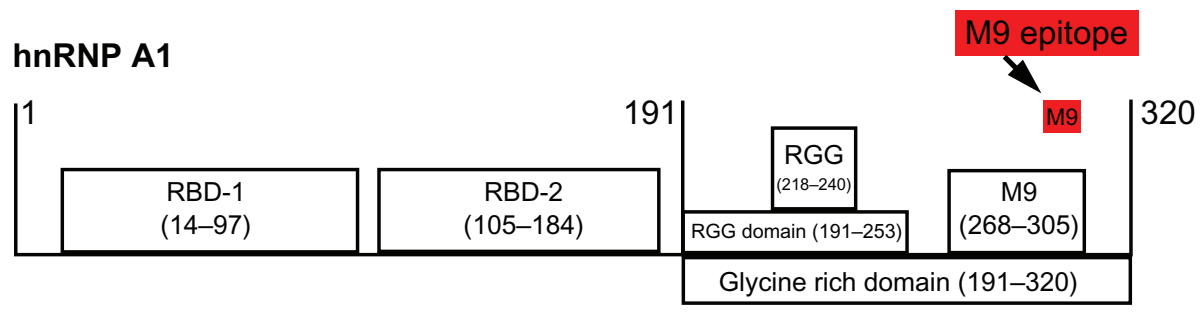

Figure I Human T-lymphotropic virus type I-associated myelopathy/tropical spastic paraparesis (HAM/TSP) and multiple sclerosis (MS) immunoglobulin G (IgG) react with the same epitope in M9. Schematic of heterogeneous nuclear ribonucleoprotein (hnRNP) AI shows the RNA-binding domains (RBDs), the RGG domain, and M9. Overlapping protein-fragment experiments showed HAM/TSP and MS IgG reacted with an epitope (amino acids [AA] 293-GQYFAKPRNQGG-304, red box), which is contained within the $M 9$ sequence (AA 268-305). ${ }^{11,127}$ 
Gene ontology output: statistically significant functional gene groups related to hnRNP A1 function

I. Biologic process:

Small GTPase mediated signal transduction (20 genes: $P=0.00532$ )

mRNA processing (14 genes: $P=0.00870)$

II. Molecular function

Ran GTPase binding (3 genes: $P=0.00091$ )

Small GTPase binding ( 6 genes: $P=0.00971$ )

Small GTPase regulator activity

(12 genes: $P=0.00617$ )

III. Cellular component

Nucleoplasm (20 genes: $P=0.00158$ )

Nuclear envelope (9 genes: $P=0.00656$ )

Nuclear membrane ( 7 genes: $P=0.00656)$

Nuclear membrane part $(7$ genes: $P=0.00544)$

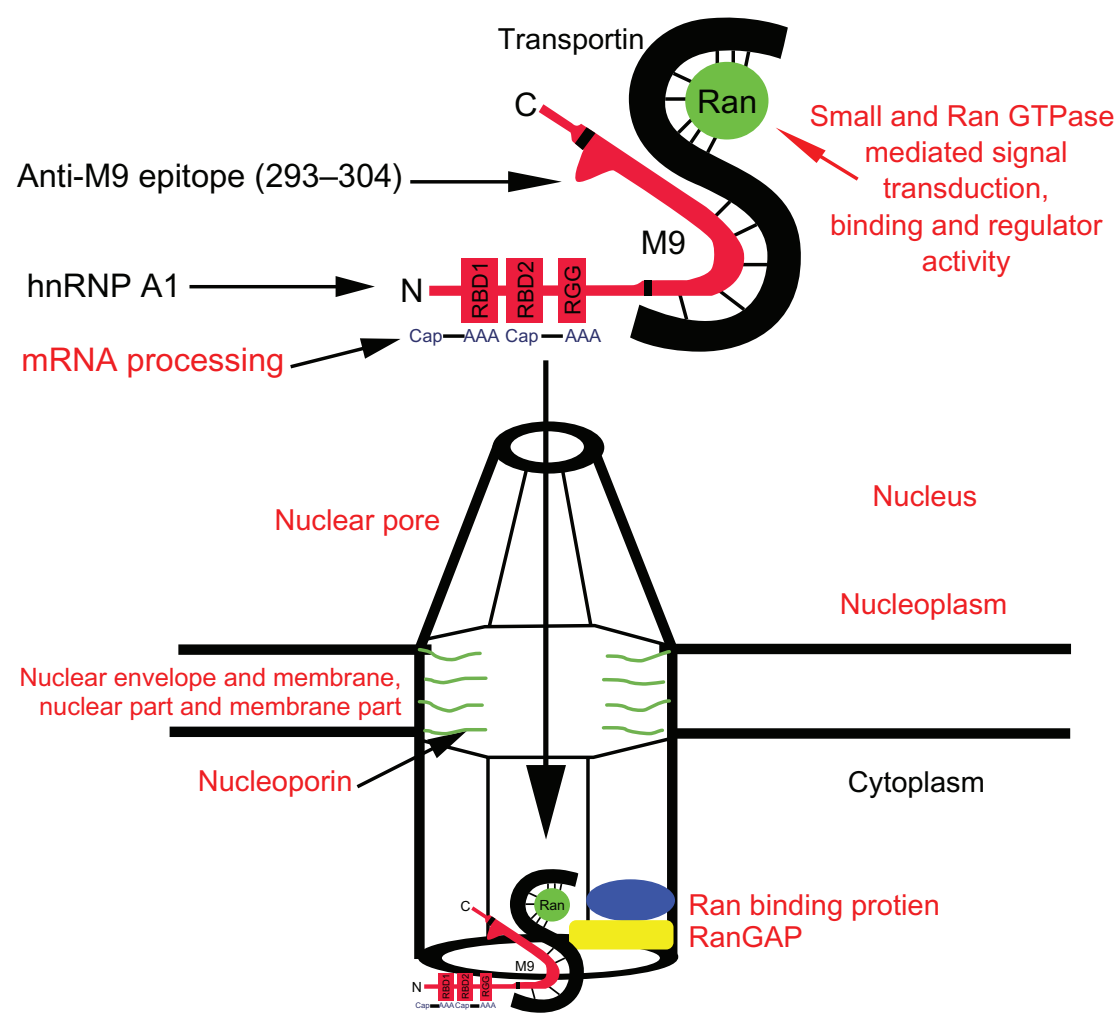

Figure 2 Genes identified by Gene Ontology are directly related to heterogeneous nuclear ribonucleoprotein (hnRNP) AI function. The gene categories and some individual genes affected by the anti-M9 antibodies are shown in red type. The complete M9 sequence (amino acids [AA] 268-305) is elongated for emphasis and bordered by the black lines within hnRNP AI. Transportin binds the M9 region at AA 263-289. AA 293-304, which are recognized by the multiple sclerosis and human T-lymphotropic virus type I-associated myelopathy/tropical spastic paraparesis immunoglobulin $\mathrm{G}$ anti-M9 immune response, are not bound to transportin, and thus are available for antibody binding. ${ }^{\prime \prime}$

Abbreviation: GTP, guanosine triphosphate.

(Figure 2). ${ }^{11,139-142}$ The second bioinformatics approach we utilized relied on a text-mining system that queries Medline abstracts called GeneIndexer (Computable Genomix, Memphis, TN). ${ }^{143}$ We used GeneIndexer to identify genes that correlate with the neural systems affected and the clinical symptoms present in progressive MS and HAM/ TSP patients. By querying the identical 866 gene set with the clinical terms paraplegia, spastic, weakness, motor, and sensory and comparing them to nonspecific search terms, GeneIndexer identified networks of genes that correlated strongly with neurodegeneration of the neural systems damaged, and the clinical phenotype expressed, by patients with progressive MS and HAM/TSP (Table 2, column 1). Most notably, the SPGs were involved. Following this output, we manually reviewed the manuscripts (identified by GeneIndexer, which were derived from Medline abstracts) related to each of these genes, and categorized them according to their primary functions (unpublished observation) (Table 2). Importantly, these changes in gene expression in neuronal cell lines were confirmed in neurons isolated from the brains of HAM/TSP and progressive MS patients, suggesting the changes found in vitro are clinically and pathologically relevant. ${ }^{11}$

These data suggest a strong association might exist between hnRNP A1 and the SPGs. To prove such an association exists, we tested for molecular interactions between hnRNP A1 and spastin (SPG4). Following immunoprecipitation of neuronal lysates with anti-hnRNP A1 antibodies, we found that spastin protein was bound to hnRNP A1. ${ }^{11}$ This interaction was confirmed by immunohistochemistry, which revealed that spastin and hnRNP A1 colocalized within the nuclei of neurons. ${ }^{11}$ In separate experiments (Figure 3 ), we performed immunoprecipitation of neuronal lysates using hnRNP A1 antibodies, and examined the resulting complex for the presence of spastin mRNA. Following immunoprecipitation with anti-hnRNP A1 antibodies, there was enrichment of the spastin mRNA signal indicative of the binding of spastin mRNA to hnRNP A1 (unpublished observation) (Figure 3 ). In contrast, there was no signal following immunoprecipitation with a nonspecific antibody, confirming the specificity of spastin mRNA binding to hnRNP A1. These experiments confirm a biological interaction between the 
Table 2 Gene clusters (color coded) identified by a text-mining database using clinical search terms following anti-hnRNP AI-M9 antibody transfection into neurons (column I, color coded) and their primary functions (columns 2-7)

\begin{tabular}{|c|c|c|c|c|c|c|}
\hline Name & $\begin{array}{l}\text { Neuronal } \\
\text { Transport }\end{array}$ & Mitochondria & $\begin{array}{l}\text { Ubiquitin } \\
\text { Proteosome } \\
\text { System/ } \\
\text { Autophagy }\end{array}$ & $\begin{array}{l}\text { Endosome } \\
\text { Lysosome } \\
\text { Peroxisome }\end{array}$ & Myelination & $\begin{array}{l}\text { Axonal } \\
\text { Integrity }\end{array}$ \\
\hline \multicolumn{7}{|l|}{ spg 4} \\
\hline \multicolumn{7}{|l|}{ spg 7} \\
\hline \multicolumn{7}{|l|}{ spg 20} \\
\hline \multicolumn{7}{|l|}{$\operatorname{atxn} 3$} \\
\hline \multicolumn{7}{|l|}{ slc6a8 } \\
\hline \multicolumn{7}{|l|}{ pnmal } \\
\hline \multicolumn{7}{|l|}{ usp 14} \\
\hline \multicolumn{7}{|l|}{ alms I } \\
\hline \multicolumn{7}{|l|}{ creldI } \\
\hline \multicolumn{7}{|l|}{ dym } \\
\hline \multicolumn{7}{|c|}{ surfl } \\
\hline \multirow{2}{*}{\multicolumn{7}{|c|}{$\begin{array}{l}\text { wbscr20c } \\
\text { citrin }\end{array}$}} \\
\hline \multirow{2}{*}{\multicolumn{7}{|c|}{$\begin{array}{l}\text { citrin } \\
\text { ulk2 }\end{array}$}} \\
\hline & & & & & & \\
\hline \multicolumn{7}{|l|}{$\mathrm{mig} / 2$} \\
\hline \multicolumn{7}{|l|}{$\operatorname{sem} 4 f$} \\
\hline \multicolumn{7}{|l|}{ abcdl } \\
\hline \multicolumn{7}{|l|}{ ahl } \\
\hline \multicolumn{7}{|l|}{ arsd } \\
\hline \multirow{2}{*}{\multicolumn{7}{|c|}{$\frac{\text { atpl I la }}{\text { dgcr6 }}$}} \\
\hline \multicolumn{6}{|l|}{ dgcr6 } & \\
\hline \multicolumn{7}{|l|}{ fam $|3 a|$} \\
\hline \multicolumn{7}{|c|}{ pom $121 \mathrm{c}$} \\
\hline \multirow{2}{*}{\multicolumn{7}{|c|}{$\begin{array}{l}44 \mid 253 \\
\mathrm{mid} 2\end{array}$}} \\
\hline \multicolumn{5}{|l|}{ mid2 } & & \\
\hline \multicolumn{7}{|l|}{ psap } \\
\hline \multicolumn{7}{|l|}{ ofd I } \\
\hline psen I & & & & & & \\
\hline psen2 & & & & & & \\
\hline sqstm I & & & & & & \\
\hline cutl2 & & & & & & \\
\hline etvl & & & & & & \\
\hline kif5C & & & & & & \\
\hline ift20 & & & & & & \\
\hline mytII & & & & & & \\
\hline neurgrin & & & & & & \\
\hline $\mathrm{nrgl}$ & & & & & & \\
\hline ift88 & & & & & & \\
\hline
\end{tabular}

anti-M9 autoimmune response and neurodegeneration, as suggested by the bioinformatics analyses. ${ }^{11}$

\section{A link between autoimmunity and mechanisms of neurodegeneration}

In summary, HAM/TSP and MS patients make antibodies to an epitope contained within the M9 region of hnRNP A1, an RBP that plays a critical role in RNA metabolism. ${ }^{11,130,131}$ Alterations in RBP function are associated with neurodegeneration. ${ }^{103}$ Anti-M9 antibodies caused neurodegeneration, loss of neuronal processes, and altered genes related to hnRNP A1 function and mechanisms of neurodegeneration associated with the clinical phenotype of HAM/TSP and progressive MS patients. ${ }^{11}$ Thus, a link between autoimmunity, clinical phenotype, and neurodegeneration has been identified. M9 is the nuclear export sequence and nuclear localization sequence of hnRNP A1, which is required for the "nonclassical" (transportinmediated) pathway of nucleocytoplasmic transport. . $^{14,127,141,144}$ This is of particular interest considering that importins and exportins, which are required for "classical" ( $\beta$-importinmediated) nucleocytoplasmic transport, play a crucial 

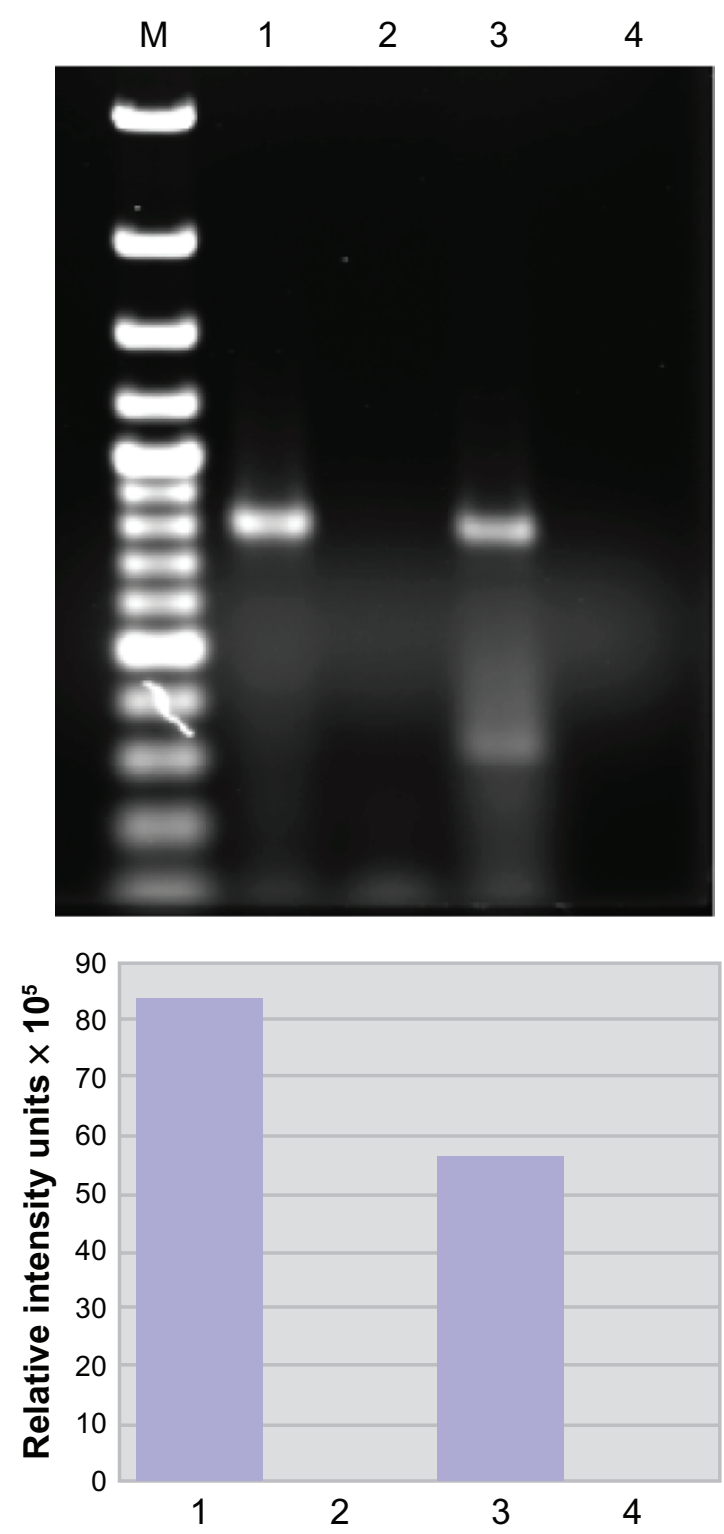

Figure 3 Spastin mRNA is bound to heterogeneous nuclear ribonucleoprotein (hnRNP) $\mathrm{Al}$ in neuronal cells. Upper panel: agarose gel. Compared to the neuronal lysate without immunoprecipitation or input (lane 3), there is an enriched spastin mRNA signal following immunoprecipitation with anti-hnRNP AI mouse monoclonal antibodies (lane I). In contrast, spastin mRNA was not isolated following immunoprecipitation with a nonspecific control antibody - mouse lgG (lane 2). Lane 4 used spastin primers without lysate (control for DNA contamination). Lower panel: the image was analyzed using ImageQuant software, which provided relative fluorescent intensity of the bands.

role in nerve injury, ${ }^{145-148}$ and recently were shown to contribute to neurodegeneration in MS. ${ }^{148,149}$ Specifically, in neurons exposed to TNF- $\alpha$, the transcription factor histone deacetylase 1 was transported from the nucleus to the cytoplasm utilizing the $\beta$-importin-mediated nucleocytoplasmic transport system, which resulted in neurodegeneration in a model of MS. ${ }^{148}$ Similar findings were observed in experiments involving the transport of hnRNP
A1 (unpublished observation) (Figure 4). Interestingly, spastin contains several nuclear export sequences and nuclear localization sequences, and thus is involved in classical ( $\beta$-importin-mediated) nucleocytoplasmic transport. ${ }^{150}$ Our data indicate a molecular interaction exists between spastin and hnRNP A1 (Figure 5), thus implicating an interaction between classical and nonclassical nucleocytoplasmic transport, which is a novel experimental observation. How might the anti-M9 immune response directed at the nonclassical nucleocytoplasmic transport system alter the classical nucleocytoplasmic transport system? Although this is not yet known, several possibilities exist. Notably, both the nonclassical and classical nucleocytoplasmic transport pathways are tightly regulated and require the binding of RanGTP to a $\beta$-karyopherin (transportin for hnRNP A1 and a $\beta$-importin for spastin) to function (Figure 2). ${ }^{11,139-142,151}$ Thus, both pathways are regulated by the same system and an interruption in one may affect the other. For example, binding of anti-M9 antibodies to hnRNP A1 might interrupt the finely tuned regulation of RanGTP, thus altering the classical nucleocytoplasmic transport of spastin. Alternatively, anti-M9 antibodies might sterically hinder hnRNP A1's binding to spastin protein. Finally, considering our data showing that spastin RNA binds hnRNP A1, anti-M9 antibodies might interfere with spastin's transport and subsequent translation or localization to specific neuronal sites. Importantly, in addition to interaction with the nuclear pore and nucleocytoplasmic transport, spastin contributes to the function of other neuronal processes (Figure 5). Spastin contains an AAA site and thus is a member of the ATPases associated with various cellular activities, which are involved in microtubule regulation, as well as proteosome and endosome function. ${ }^{28,100,102}$ Spastin contains a microtubule interacting and trafficking protein site, ${ }^{100,152}$ and has been shown to play a role in microtubule stability and axonal transport in neurons, ${ }^{100}$ and in turn in normal synaptic growth and transmission. ${ }^{101}$ In addition, spastin has been shown to play an important role in axonal transport, which when disrupted results in neurodegeneration. . $8,99,100,152^{2}$

Spastin is just one example of how the anti-hnRNP A1 M9 immune response might contribute to neurodegeneration. As shown in Table 2, other genes were altered by the anti-M9 immune response. ${ }^{11}$ Future studies are needed to tease out the details of how these other groups of genes might contribute to mechanisms of neurodegeneration, including those potentially related to the progressive cognitive decline seen in MS patients, ${ }^{35,153,154}$ which has not yet been addressed in this model. 
No TNF $\alpha$
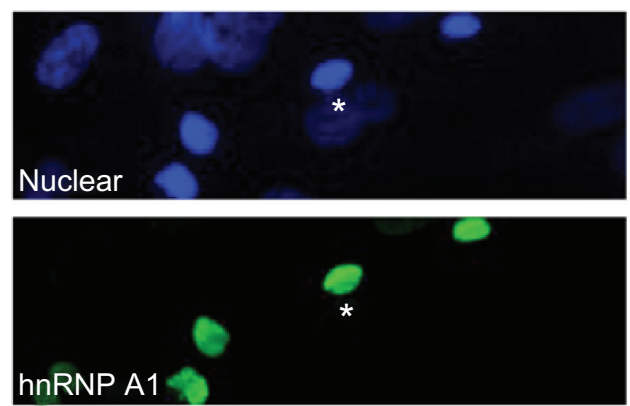

$(+)$ TNF $\alpha$
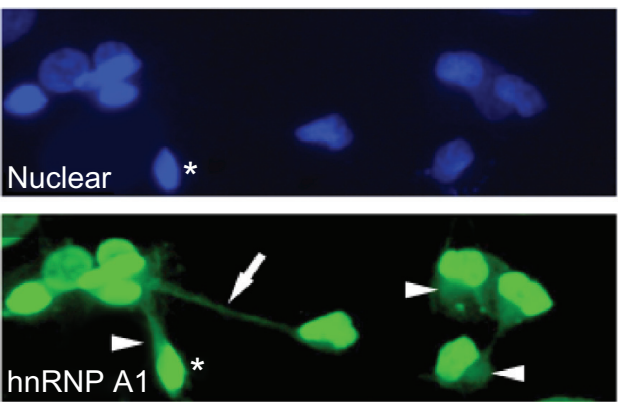

Figure 4 Heterogeneous nuclear ribonucleoprotein (hnRNP) Al localization following TNF- $\alpha$ exposure in neurons. Without TNF- $\alpha$ exposure, hnRNP Al is localized to nuclei $(*)$ in dNT-2 neurons (left panels) (blue nuclear stain is diamidino-2-phenylindole; green stain is immunohistochemistry using an anti-hnRNP AI antibody). Following exposure to TNF- $\alpha$ (400 ng/mL, $50 \mathrm{mM}$ glutamate, 30 minutes), hnRNP Al is also found in the cytoplasm (arrowheads) and neuronal processes (arrow) of neurons (lower right panel).

Abbreviation: TNF, tumor necrosis factor.
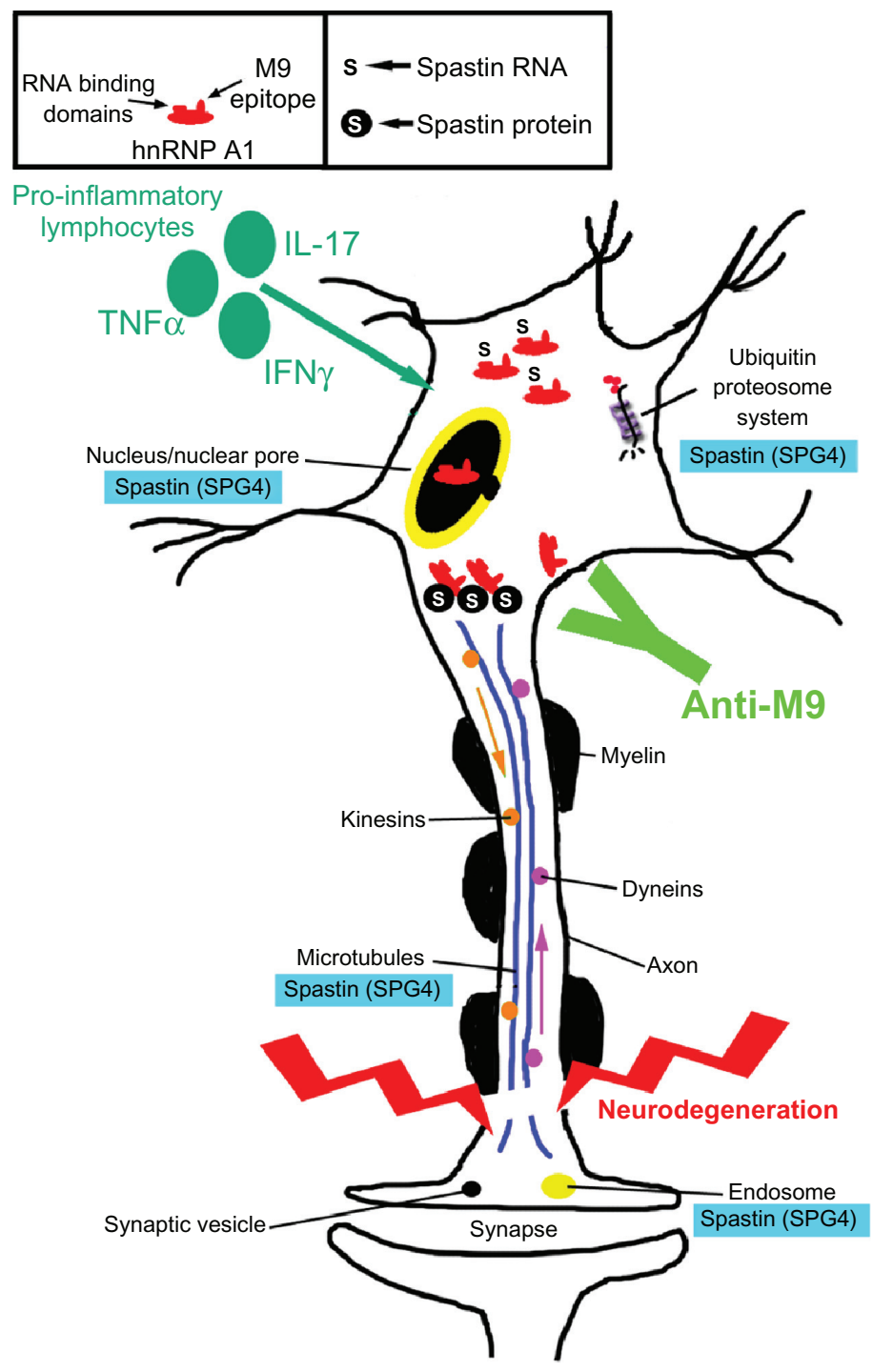

Figure 5 Potential contribution of the anti-heterogeneous nuclear ribonucleoprotein (hnRNP) Al M9 immune response to neurodegeneration in immune-mediated neurological disease. Multiple sclerosis and human T-lymphotropic virus type I-associated myelopathy/tropical spastic paraparesis patients develop antibodies to an epitope contained within the M9 region of hnRNP AI (box). hnRNP AI has been shown to interact molecularly with spastin RNA and protein (box and figure). The anti-M9 immune response altered spastin RNA levels, which may alter spastin function at multiple sites within neurons (blue boxes). The combination of proinflammatory cytokines and the anti-M9 immune response might contribute to neurodegeneration in immune-mediated neurological disease. Abbreviations: TNF, tumor necrosis factor; IFN, interferon; IL, interleukin; SPG, spinal paraplegia gene. 


\section{Conclusion}

Taken together, these data suggest that neurodegeneration in MS involves multiple processes. One of several possible links between autoimmunity and neurodegeneration in neurological disease has been described. The target is hnRNP A1 in neurons and the immune response is antibodies to M9, its shuttling domain required for nucleocytoplasmic transport. Anti-M9 antibodies identified integrated networks of genes that maintain neuronal and axonal function and contribute to mechanisms of neurodegeneration related to the clinical phenotype expressed by patients with immune-mediated neurological diseases, such as progressive MS and HAM/TSP. Comprehensive analyses of this type of phenotype-specific mechanism of neurodegeneration may reveal novel strategies to treat these unremitting progressive neurological diseases.

\section{Acknowledgments}

This work is based upon work supported by the Office of Research and Development, Medical Research Service, Department of Veterans Affairs. This study was funded by a VA Merit Review Award (to MCL) and the University of Tennessee Health Science Center Multiple Sclerosis Research Fund.

\section{Disclosure}

Drs Michael Levin and Sangmin Lee have a patent pending titled "Biomarker for neurodegeneration in neurological disease." All other authors report no conflicts of interest in this paper.

\section{References}

1. Dutta R, Trapp BD. Pathogenesis of axonal and neuronal damage in multiple sclerosis. Neurology. 2007;68(22 Suppl 3):S22-S31; discussion S43-S54.

2. Peterson JW, Trapp BD. Neuropathobiology of multiple sclerosis. Neurol Clin. 2005;23(1):107-129, vi-vii.

3. Noseworthy J, Lucchinetti C, Rodgriguez M, Weinshenker B. Multiple sclerosis. N Engl J Med. 2000;343(13):938-952.

4. Lassmann H, Bruck W, Lucchinetti CF. The immunopathology of multiple sclerosis: an overview. Brain Pathol. 2007;17(2):210-218.

5. Filippi M, Rovaris M, Rocca MA. Imaging primary progressive multiple sclerosis: the contribution of structural, metabolic, and functional MRI techniques. Mult Scler. Jun 2004;10 Suppl 1:S36-S44, discussion S44-S45.

6. Barkhof F, Calabresi PA, Miller DH, Reingold SC. Imaging outcomes for neuroprotection and repair in multiple sclerosis trials. Nat Rev Neurol. 2009;5(5):256-266.

7. DeLuca GC, Ramagopalan SV, Cader MZ, et al. The role of hereditary spastic paraplegia related genes in multiple sclerosis. A study of disease susceptibility and clinical outcome. J Neurol. 2007;254(9):1221-1226.

8. Soldan S, Berti R, Salem N, et al. Association of human herpes virus 6 (HHV-6) with multiple sclerosis: increased IgM response to HHV-6 early antigen and detection of serum HHV-6 DNA. Nat Med. 1997; 3(12):1394-1397.
9. Sriram S, Stratton C, Yao S, et al. Chlamydia pneumonaie infection of the central nervous system in multiple sclerosis. Ann Neurol. 1999; 46(1):6-14.

10. Thacker EL, Mirzaei F, Ascherio A. Infectious mononucleosis and risk for multiple sclerosis: a meta-analysis. Ann Neurol. 2006;59(3):499-503.

11. Lee S, Xu L, Shin Y, et al. A potential link between autoimmunity and neurodegeneration in immune-mediated neurological disease. J Neuroimmunol. 2011;235(1-2):56-69.

12. Lee S, Levin MC. Molecular mimicry in neurological disease: what is the evidence? Cell Mol Life Sci. 2008;65(7-8):1161-1175.

13. Lee SM, Morocos Y, Jang H, Stuart JM, Levin MC. HTLV-1 induced molecular mimicry in neurologic disease. In: Oldstone M, editor. Molecular Mimicry: Infection Inducing Autoimmune Disease. New York: Springer; 2005.

14. Levin MC, Lee SM, Kalume F, et al. Autoimmunity due to molecular mimicry as a cause of neurological disease. Nat Med. May 2002;8(5): 509-513.

15. Wucherpfennig KW. Infectious triggers for inflammatory neurological diseases. Nat Med. 2002;8(5):455-457.

16. Poeisz B, Ruscetti F, Gazdar A, Bunn P, Minna J, Gallo R. Detection and isolation of type $\mathrm{C}$ retrovirus particles from fresh and cultured lymphocytes of a patient with cutaneous T cell lymphoma. Proc Natl Acad Sci. 1980;77(12):7415-7419.

17. Gessain A, Vernant J, Maurs L, et al. Antibodies to human T-lymphotropic virus I in patients with tropical spastic paraparesis. Lancet. 1985;2:407-410.

18. Osame M, Usuku K, Izumo S, et al. HTLV-I associated myelopathy, a new clinical entity. Lancet. 1986;1(8488):1031-1032.

19. Levin M, Lehky T, Flerlage N, et al. Immunopathogenesis of HTLV-1 associated neurologic disease based on a spinal cord biopsy from a patient with HTLV-1 associated myelopathy/tropical spastic paraparesis (HAM/TSP). N Engl J Med. 1997;336:839-845.

20. Levin MC, Jacobson S. HTLV-I associated myelopathy/tropical spastic paraparesis (HAM/TSP): a chronic progressive neurologic disease associated with immunologically mediated damage to the central nervous system. J Neurovirol. 1997;3(2):126-140.

21. Araujo AQ, Silva MT. The HTLV-1 neurological complex. Lancet Neurol. 2006;5(12):1068-1076.

22. Verdonck K, Gonzalez E, Van Dooren S, Vandamme AM, Vanham G, Gotuzzo E. Human T-lymphotropic virus 1: recent knowledge about an ancient infection. Lancet Infect Dis. 2007;7(4):266-281.

23. Jacobson S. The NK cell as a new player in the pathogenesis of HTLV-I associated neurologic disease. Virulence. 2010;1(1):8-9.

24. Martin F, Bangham CR, Ciminale V, et al. Conference highlights of the 15th International Conference on Human Retrovirology: HTLV and related retroviruses, June 4-8, 2011. Leuven, Gembloux, Belgium. Retrovirology. 2011;8:86.

25. Puccioni-Sohler M, Yamano Y, Rios M, et al. Differentiation of HAM/ TSP from patients with multiple sclerosis infected with HTLV-I. Neurology. 2007;68(3):206-213.

26. Khan RB, Bertorini TE, Levin MC. HTLV-1 and its neurological complications. Neurologist. 2001;7(5):271-278.

27. Soderblom C, Blackstone C. Traffic accidents: molecular genetic insights into the pathogenesis of the hereditary spastic paraplegias. Pharmacol Ther. 2006;109(1-2):42-56.

28. Salinas S, Proukakis C, Crosby A, Warner TT. Hereditary spastic paraplegia: clinical features and pathogenetic mechanisms. Lancet Neurol. 2008;7(12):1127-1138.

29. Umehara F, Abe M, Koreeda Y, Izumo S, Osame M. Axonal damage revealed by accumulation of beta-amyloid precursor protein in HTLVI-associated myelopathy. J Neurol Sci. 2000;176(2):95-101.

30. Jernigan M, Morcos Y, Lee SM, Dohan FC Jr, Raine C, Levin MC. IgG in brain correlates with clinicopathological damage in HTLV-1 associated neurologic disease. Neurology. 2003;60(8):1320-1327.

31. Deluca GC, Ebers GC, Esiri MM. The extent of axonal loss in the long tracts in hereditary spastic paraplegia. Neuropathol Appl Neurobiol. 2004;30(6):576-584. 
32. DeLuca GC, Ebers GC, Esiri MM. Axonal loss in multiple sclerosis: a pathological survey of the corticospinal and sensory tracts. Brain. 2004;127(Pt 5):1009-1018.

33. Izumo S. Neuropathology of HTLV-1-associated myelopathy (HAM/TSP). Neuropathology. Epub June 21, 2010.

34. Trapp BD, Nave KA. Multiple sclerosis: an immune or neurodegenerative disorder? Annu Rev Neurosci. 2008;31:247-269.

35. Geurts JJ, Barkhof F. Grey matter pathology in multiple sclerosis. Lancet Neurol. 2008;7(9):841-851.

36. Kutzelnigg A, Lucchinetti CF, Stadelmann C, et al. Cortical demyelination and diffuse white matter injury in multiple sclerosis. Brain. 2005;128(Pt 11):2705-2712.

37. Kornek B, Storch MK, Weissert R, et al. Multiple sclerosis and chronic autoimmune encephalomyelitis: a comparative quantitative study of axonal injury in active, inactive, and remyelinated lesions. Am J Pathol. 2000;157(1):267-276.

38. Gold R, Linington C, Lassmann H. Understanding pathogenesis and therapy of multiple sclerosis via animal models: 70 years of merits and culprits in experimental autoimmune encephalomyelitis research. Brain 2006;129(Pt 8):1953-1971.

39. Aboul-Enein F, Weiser P, Hoftberger R, Lassmann H, Bradl M. Transient axonal injury in the absence of demyelination: a correlate of clinical disease in acute experimental autoimmune encephalomyelitis. Acta Neuropathol (Berl). 2006;111(6):539-547.

40. Lassmann H. Multiple sclerosis: is there neurodegeneration independent from inflammation? J Neurol Sci. 2007;259(1-2):3-6.

41. Bjartmar C, Wujek JR, Trapp BD. Axonal loss in the pathology of MS: consequences for understanding the progressive phase of the disease. J Neurol Sci. 2003;206(2):165-171.

42. Lassmann H, van Horssen J. The molecular basis of neurodegeneration in multiple sclerosis. FEBS Lett. 2011;585(23):3715-3723.

43. Bennett JL, Stuve O. Update on inflammation, neurodegeneration, and immunoregulation in multiple sclerosis: therapeutic implications. Clin Neuropharmacol. 2009;32(3):121-132.

44. Steinman L. Mixed results with modulation of TH-17 cells in human autoimmune diseases. Nat Immunol. 2010;11(1):41-44.

45. McFarland HF, Martin R. Multiple sclerosis: a complicated picture of autoimmunity. Nat Immunol. 2007;8(9):913-919.

46. Lisak RP. Neurodegeneration in multiple sclerosis: defining the problem. Neurology. 2007;68(22 Suppl 3):S5-S12; discussion S43-S54.

47. Frohman EM, Racke MK, Raine CS. Multiple sclerosis - the plaque and its pathogenesis. N Engl J Med. 2006;354(9):942-955.

48. Frischer JM, Bramow S, Dal-Bianco A, et al. The relation between inflammation and neurodegeneration in multiple sclerosis brains. Brain May 2009;132(Pt 5):1175-1189.

49. Trapp B, Peterson J, Ransohoff R, Rudick R, Mork S, Bo L. Axonal transection in the lesions of multiple sclerosis. N Engl J Med. 1998; 338(5):278-285

50. Lassmann H, Lucchinetti CF. Cortical demyelination in CNS inflammatory demyelinating diseases. Neurology. 2008;70(5):332-333.

51. Lucchinetti CF, Popescu BF, Bunyan RF, et al. Inflammatory cortical demyelination in early multiple sclerosis. $N$ Engl J Med. 2011;365(23): 2188-2197.

52. Peterson JW, Bo L, Mork S, Chang A, Trapp BD. Transected neurites, apoptotic neurons, and reduced inflammation in cortical multiple sclerosis lesions. Ann Neurol. 2001;50(3):389-400.

53. Fisher E, Lee JC, Nakamura K, Rudick RA. Gray matter atrophy in multiple sclerosis: a longitudinal study. Ann Neurol. 2008;64(3):255-265.

54. Fisniku LK, Chard DT, Jackson JS, et al. Gray matter atrophy is related to long-term disability in multiple sclerosis. Ann Neurol. 2008;64(3): 247-254

55. Geurts JJ. Is progressive multiple sclerosis a gray matter disease? Ann Neurol. 2008;64(3):230-232.

56. Serafini B, Rosicarelli B, Magliozzi R, Stigliano E, Aloisi F. Detection of ectopic B-cell follicles with germinal centers in the meninges of patients with secondary progressive multiple sclerosis. Brain Pathol. 2004;14(2):164-174.
57. Magliozzi R, Howell OW, Reeves C, et al. A gradient of neuronal loss and meningeal inflammation in multiple sclerosis. Ann Neurol. 2010;68(4):477-493.

58. Ganter P, Prince C, Esiri MM. Spinal cord axonal loss in multiple sclerosis: a post-mortem study. Neuropathol Appl Neurobiol. 1999;25(6):459-467.

59. Lovas G, Szilagyi N, Majtenyi K, Palkovits M, Komoly S. Axonal changes in chronic demyelinated cervical spinal cord plaques. Brain. 2000;123(Pt 2):308-317.

60. DeLuca GC, Williams K, Evangelou N, Ebers GC, Esiri MM. The contribution of demyelination to axonal loss in multiple sclerosis. Brain. 2006;129(Pt 6):1507-1516.

61. Evangelou N, DeLuca GC, Owens T, Esiri MM. Pathological study of spinal cord atrophy in multiple sclerosis suggests limited role of local lesions. Brain. 2005;128(Pt 1):29-34.

62. Izumo S, Higuchi I, Ijichi T, et al. Neuropathological study in two autopsy cases of HTLV-1 associated myelopathy (HAM). In: Iwasaki Y, editor. Neuropathology of HAM/TSP in Japan. Proceedings of the First Workshop on Neuropathology of Retrovirus Infections; August 31, 1989; Tokyo, Japan. Sendai, Japan: Tohuku University Press; 1989:7-17.

63. Izumo S, Umehara F, Osame M. HTLV-I-associated myelopathy. Neuropathology. 2000;20 Suppl:S65-S68.

64. Evangelou IE, Oh U, Massoud R, Jacobson S. HTLV-I-associated myelopathy/tropical spastic paraparesis: semiautomatic quantification of spinal cord atrophy from 3-dimensional MR images. J Neuroimaging. Epub February 3, 2012.

65. Furby J, Hayton T, Anderson V, et al. Magnetic resonance imaging measures of brain and spinal cord atrophy correlate with clinical impairment in secondary progressive multiple sclerosis. Mult Scler. 2008;14(8):1068-1075.

66. Umehara F, Izumo S, Nakagawa M, et al. Immunocytochemical analysis of the cellular infiltrate in the spinal cord lesions in HTLV-I-associated myelopathy. J Neuropathol Exp Neurol. 1993;52(4):424-430.

67. Matsuoka E, Takenouchi N, Hashimoto K, et al. Perivascular T cells are infected with HTLV-I in the spinal cord lesions with HTLV-Iassociated myelopathy/tropical spastic paraparesis: double staining of immunohistochemistry and polymerase chain reaction in situ hybridization. Acta Neuropathol (Berl). 1998;96(4):340-346.

68. Moritoyo T, Reinhart T, Moritoyo H, et al. Human T-lymphotropic virus type I associated myelopathy and tax gene expression in CD4+ T lymphocytes. Ann Neurol. 1996;40(1):84-90.

69. Araya N, Sato T, Yagishita N, et al. Human T-lymphotropic virus type 1 (HTLV-1) and regulatory T cells in HTLV-1-associated neuroinflammatory disease. Viruses. 2011;3(9):1532-1548.

70. Matsuura E, Yamano Y, Jacobson S. Neuroimmunity of HTLV-I Infection. J Neuroimmune Pharmacol. 2010;5(3):310-325.

71. Takenouchi N, Yao K, Jacobson S. Immunopathogensis of HTLV-I associated neurologic disease: molecular, histopathologic, and immunologic approaches. Front Biosci. 2004;9:2527-2539.

72. Bangham CR, Osame M. Cellular immune response to HTLV-1. Oncogene. 2005;24(39):6035-6046.

73. Bangham CR, Meekings K, Toulza F, et al. The immune control of HTLV-1 infection: selection forces and dynamics. Front Biosci. 2009;14:2889-2903.

74. Bangham CR. The immune response to HTLV-I. Curr Opin Immunol. 2000;12(4):397-402.

75. Jacobson S, Shida H, McFarlin DE, FauciAS, Koenig S. Circulating CD8+ cytotoxic T lymphocytes specific for HTLV-I pX in patients with HTLV-I associated neurological disease. Nature. 1990;348(6298):245-248.

76. Lal RB, Giam C-Z, Coligan JE, Rudolph DL. Differential immune responsiveness to the immunodominant epitopes of regulatory proteins (tax and rex) in human $\mathrm{T}$ cell lymphotropic virus type 1-associated myelopathy. J Infect Dis. 1994;169(3):496-503.

77. Kubota R, Furukawa Y, Izumo S, Usuku K, Osame M. Degenerate specificity of HTLV-1-specific CD8+ T cells during viral replication in patients with HTLV-1-associated myelopathy (HAM/TSP). Blood. 2003;101(8):3074-3081. 
78. Goon PK, Hanon E, Igakura T, et al. High frequencies of Th1-type CD4(+) T cells specific to HTLV-1 Env and Tax proteins in patients with HTLV-1-associated myelopathy/tropical spastic paraparesis. Blood. 2002;99(9):3335-3341.

79. Jeffery KJ, Usuku K, Hall SE, et al. HLA alleles determine human T-lymphotropic virus-I (HTLV-I) proviral load and the risk of HTLV-I-associated myelopathy. Proc Natl Acad Sci U S A. 1999;96(7): $3848-3853$

80. Macnamara A, Rowan A, Hilburn S, et al. HLA class I binding of HBZ determines outcome in HTLV-1 infection. PLoS Pathog. 2010;6(9): e1001117.

81. Saxena A, Martin-Blondel G, Mars LT, Liblau RS. Role of CD8 $\mathrm{T}$ cell subsets in the pathogenesis of multiple sclerosis. FEBS Lett. 2011;585(23):3758-3763.

82. Schneider R, Mohebiany AN, Ifergan I, et al. B cell-derived IL-15 enhances CD8 T cell cytotoxicity and is increased in multiple sclerosis patients. J Immunol. 2011;187(8):4119-4128.

83. Yamano Y, Araya N, Sato T, et al. Abnormally high levels of virus-infected IFN-gamma+ CCR4+ CD4+CD25+ T cells in a retrovirus-associated neuroinflammatory disorder. PloS One. 2009;4(8): e6517.

84. Norris PJ, Hirschkorn DF, DeVita DA, Lee TH, Murphy EL. Human $\mathrm{T}$ cell leukemia virus type 1 infection drives spontaneous proliferation of natural killer cells. Virulence. 2010;1(1):19-28.

85. Nagai M, Usuku K, Matsumoto W, et al. Analysis of HTLV-1 proviral load in 202 HAM/TSP patients and 243 asymptomatic HTLV-1 carriers: high proviral load strongly predisposes to HAM/TSP. J Neurovirol. 1998;4(6):586-593.

86. Olindo S, Lezin A, Cabre P, et al. HTLV-1 proviral load in peripheral blood mononuclear cells quantified in $100 \mathrm{HAM}$ /TSP patients: a marker of disease progression. J Neurol Sci. 2005;237(1-2):53-59.

87. Montanheiro PA, Oliveira AC, Posada-Vergara MP, et al. Human T-cell lymphotropic virus type I (HTLV-I) proviral DNA viral load among asymptomatic patients and patients with HTLV-I-associated myelopathy/tropical spastic paraparesis. Braz J Med Biol Res. 2005; 38(11):1643-1647.

88. Tattermusch S, Skinner JA, Chaussabel D, et al. Systems biology approaches reveal a specific interferon-inducible signature in HTLV-1 associated myelopathy. PLoS Pathog. 2012;8(1):e1002480.

89. Goon PK, Igakura T, Hanon E, et al. High circulating frequencies of tumor necrosis factor alpha- and interleukin-2-secreting human T-lymphotropic virus type 1 (HTLV-1)-specific CD4+ T cells in patients with HTLV-1-associated neurological disease. J Virol. 2003;77(17): 9716-9722.

90. Waxman SG. Axonal conduction and injury in multiple sclerosis: the role of sodium channels. Nat Rev Neurosci. 2006;7(12):932-941.

91. Dutta R, Trapp B. Mechanisms of neuronal dysfunction and degeneration in multiple sclerosis. Prog Neurobiol. 2011;93(1):1-12.

92. Dutta R, McDonough J, Yin X, et al. Mitochondrial dysfunction as a cause of axonal degeneration in multiple sclerosis patients. Ann Neurol. 2006;59(3):478-489.

93. Campbell GR, Ziabreva I, Reeve AK, et al. Mitochondrial DNA deletions and neurodegeneration in multiple sclerosis. Ann Neurol. 2011;69(3):481-492.

94. Haider L, Fischer MT, Frischer JM, et al. Oxidative damage in multiple sclerosis lesions. Brain. 2011;134(Pt 7):1914-1924.

95. Trapp BD, Stys PK. Virtual hypoxia and chronic necrosis of demyelinated axons in multiple sclerosis. Lancet Neurol. 2009;8(3): 280-291.

96. Mahad DJ, Ziabreva I, Campbell G, et al. Mitochondrial changes within axons in multiple sclerosis. Brain. 2009;132(Pt 5):1161-1174.

97. Ferguson B, Matyszak MK, Esiri MM, Perry VH. Axonal damage in acute multiple sclerosis lesions. Brain. 1997;120(Pt 3):393-399.

98. Stokin GB, Lillo C, Falzone TL, et al. Axonopathy and transport deficits early in the pathogenesis of Alzheimer's disease. Science. 2005;307(5713):1282-1288.
99. De Vos KJ, Grierson AJ, Ackerley S, Miller CC. Role of axonal transport in neurodegenerative diseases. Annu Rev Neurosci. 2008;31: 151-173.

100. Roll-Mecak A, Vale RD. Structural basis of microtubule severing by the hereditary spastic paraplegia protein spastin. Nature. 2008; 451(7176):363-367.

101. Trotta N, Orso G, Rossetto MG, Daga A, Broadie K. The hereditary spastic paraplegia gene, spastin, regulates microtubule stability to modulate synaptic structure and function. Curr Biol. 2004;14(13): $1135-1147$.

102. Hazan J, Fonknechten N, Mavel D, et al. Spastin, a new AAA protein, is altered in the most frequent form of autosomal dominant spastic paraplegia. Nat Genet. 1999;23(3):296-303.

103. Lukong KE, Chang KW, Khandjian EW, Richard S. RNA-binding proteins in human genetic disease. Trends Genet. 2008;24(8):416-425.

104. Orr HT. FTD and ALS: genetic ties that bind. Neuron. 2011;72(2): 189-190.

105. Gao FB, Taylor JP. RNA-binding proteins in neurological disease. Brain Res. 2012;1462:1-2.

106. Polymenidou M, Lagier-Tourenne C, Hutt KR, Bennett CF, Cleveland DW, Yeo GW. Misregulated RNA processing in amyotrophic lateral sclerosis. Brain Res. 2012;1462:3-15.

107. Licatalosi DD, Darnell RB. Splicing regulation in neurologic disease. Neuron. 2006;52(1):93-101.

108. Darnell RB, Posner JB. Paraneoplastic syndromes involving the nervous system. N Engl J Med. 2003;349(16):1543-1554.

109. Owens GP, Bennett JL, Lassmann H, et al. Antibodies produced by clonally expanded plasma cells in multiple sclerosis cerebrospinal fluid. Ann Neurol. 2009;65(6):639-649.

110. Lovato L, Willis SN, Rodig SJ, et al. Related B cell clones populate the meninges and parenchyma of patients with multiple sclerosis. Brain. 2011;134(Pt 2):534-541.

111. Keegan M, Pineda AA, McClelland RL, Darby CH, Rodriguez M, Weinshenker BG. Plasma exchange for severe attacks of CNS demyelination: predictors of response. Neurology. 2002;58(1): 143-146.

112. Keegan M, Konig F, McClelland R, et al. Relation between humoral pathological changes in multiple sclerosis and response to therapeutic plasma exchange. Lancet. 2005;366(9485):579-582.

113. Elovaara I, Kuusisto H, Wu X, Rinta S, Dastidar P, Reipert B. Intravenous immunoglobulins are a therapeutic option in the treatment of multiple sclerosis relapse. Clin Neuropharmacol. 2011;34(2): 84-89.

114. Haas J, Maas-Enriquez M, Hartung HP. Intravenous immunoglobulins in the treatment of relapsing remitting multiple sclerosis - results of a retrospective multicenter observational study over five years. Mult Scler. 2005;11(5):562-567.

115. Hauser SL, Waubant E, Arnold DL, et al. B-cell depletion with rituximab in relapsing-remitting multiple sclerosis. $N$ Engl J Med. 2008; 358(7):676-688.

116. Boster A, Ankeny DP, Racke MK. The potential role of B celltargeted therapies in multiple sclerosis. Drugs. 2010;70(18): 2343-2356.

117. Meinl E, Derfuss T, Krumbholz M, Probstel AK, Hohlfeld R. Humoral autoimmunity in multiple sclerosis. J Neurol Sci. 2010; 306(1-2):180-182.

118. Brown DA, Sawchenko PE. Time course and distribution of inflammatory and neurodegenerative events suggest structural bases for the pathogenesis of experimental autoimmune encephalomyelitis. J Comp Neurol. 2007;502(2):236-260.

119. Derfuss T, Linington C, Hohlfeld R, Meinl E. Axo-glial antigens as targets in multiple sclerosis: implications for axonal and grey matter injury. J Mol Med (Berl). 2010;88(8):753-761.

120. Mathey EK, Derfuss T, Storch MK, et al. Neurofascin as a novel target for autoantibody-mediated axonal injury. $J$ Exp Med. 2007;204(10): 2363-2372. 
121. Rawes JA, Calabrese VP, Khan OA, DeVries GH. Antibodies to the axolemma-enriched fraction in the cerebrospinal fluid and serum of patients with multiple sclerosis and other neurological diseases. Mult Scler. 1997;3(6):363-369.

122. Norgren N, Edelstam A, Stigbrand T. Cerebrospinal fluid levels of neurofilament light in chronic experimental autoimmune encephalomyelitis. Brain Res Bull. 2005;67(4):264-268.

123. Sadatipour BT, Greer JM, Pender MP. Increased circulating antiganglioside antibodies in primary and secondary progressive multiple sclerosis. Ann Neurol. 1998;44(6):980-983.

124. Srivastava R, Aslam M, Kalluri SR, et al. Potassium channel KIR4.1 as an immune target in multiple sclerosis. N Engl J Med. 2012;367(2): 115-123.

125. Cross AH, Waubant E. Antibodies to potassium channels in multiple sclerosis. N Engl J Med. 2012;367(2):172-174.

126. Levin M, Krichavsky M, Berk J, et al. Neuronal molecular mimicry in immune mediated neurologic disease. Ann Neurol. 1998;44(1): 87-98.

127. Lee SM, Dunnavant FD, Jang H, Zunt J, Levin MC. Autoantibodies that recognize functional domains of hnRNPA1 implicate molecular mimicry in the pathogenesis of neurological disease. Neurosci Lett. 2006;401(1-2):188-193.

128. Lee S, Shin Y, Marler J, Levin MC. Post-translational glycosylation of target proteins implicate molecular mimicry in the pathogenesis of HTLV-1 associated neurological disease. J Neuroimmunol. 2008; 204(1-2):140-148

129. Lee S, Shin Y, Clark D, Gotuzzo E, Levin MC. Cross-reactive antibodies to target proteins are dependent upon oligomannose glycosylated epitopes in HTLV-1 associated neurological disease. J Clin Immunol. 2012;32(4):736-745.

130. Dreyfuss G, Kim VN, Kataoka N. Messenger-RNA-binding proteins and the messages they carry. Nat Rev Mol Cell Biol. 2002;3(3): 195-205.

131. Han SP, Tang YH, Smith R. Functional diversity of the hnRNPs: past, present and perspectives. Biochem J. 2010;430(3):379-392.

132. Levin MC, Lee SM, Morcos Y, Brady J, Stuart J. Cross-reactivity between immunodominant human $\mathrm{T}$ lymphotropic virus type I tax and neurons: implications for molecular mimicry. J Infect Dis. 2002; 186(10):1514-1517.

133. Kalume F, Lee SM, Morcos Y, Callaway JC, Levin MC. Molecular mimicry: cross-reactive antibodies from patients with immune-mediated neurologic disease inhibit neuronal firing. J Neurosci Res. 2004;77(1): 82-89.

134. García-Vallejo F, Domínguez MC, Tamayo O. Autoimmunity and molecular mimicry in tropical spastic paraparesis/human T-lymphotropic virus-associated myelopathy. Braz J Med Biol Res 2005;38(2):241-250.

135. Sueoka E, Yukitake M, Iwanaga K, Sueoka N, Aihara T, Kuroda Y. Autoantibodies against heterogeneous nuclear ribonucleoprotein B1 in CSF of MS patients. Ann Neurol. 2004;56(6):778-786.

136. Yukitake M, Sueoka E, Sueoka-Aragane N, et al. Significantly increased antibody response to heterogeneous nuclear ribonucleoproteins in cerebrospinal fluid of multiple sclerosis patients but not in patients with human T-lymphotropic virus type I-associated myelopathy/tropical spastic paraparesis. J Neurovirol. 2008;14(2):130-135.
137. Douglas J, Gardner L, Lee S, Shin Y, Groover C, Levin MC. Antibody transfection into neurons as a tool to study disease pathogenesis. Journal of Visualized Experiments. 2012;67:pii 4154.

138. Schmued LC, Stowers CC, Scallet AC, Xu L. Fluoro-Jade C results in ultra high resolution and contrast labeling of degenerating neurons. Brain Res. 2005;1035(1):24-31.

139. Stewart M. Molecular mechanism of the nuclear protein import cycle. Nat Rev Mol Cell Biol. 2007;8(3):195-208.

140. Conti E, Müller CW, Stewart M. Karyopherin flexibility in nucleocytoplasmic transport. Curr Opin Struct Biol. 2006;16(2): 237-244.

141. Cook A, Bono F, Jinek M, Conti E. Structural biology of nucleocytoplasmic transport. Annu Rev Biochem. 2007;76:647-671.

142. Lee BJ, Cansizoglu AE, Suel KE, Louis TH, Zhang Z, Chook YM Rules for nuclear localization sequence recognition by karyopherin beta 2. Cell. 2006;126(3):543-558.

143. Homayouni R, Heinrich K, Wei L, Berry MW. Gene clustering by latent semantic indexing of MEDLINE abstracts. Bioinformatics. 2005;21(1):104-115.

144. Michael WM, Choi M, Dreyfuss G. A nuclear export signal in hnRNP A1: a signal-mediated, temperature-dependent nuclear protein export pathway. Cell. 1995;83(3):415-422.

145. Hanz S, Perlson E, Willis D, et al. Axoplasmic importins enable retrograde injury signaling in lesioned nerve. Neuron. 2003;40(6): 1095-1104.

146. Thompson KR, Otis KO, Chen DY, Zhao Y, O’Dell TJ, Martin KC. Synapse to nucleus signaling during long-term synaptic plasticity; a role for the classical active nuclear import pathway. Neuron. 2004; 44(6):997-1009.

147. Yudin D, Hanz S, Yoo S, et al. Localized regulation of axonal RanGTPase controls retrograde injury signaling in peripheral nerve. Neuron. 2008;59(2):241-252.

148. Kim JY, Shen S, Dietz K, et al. HDAC1 nuclear export induced by pathological conditions is essential for the onset of axonal damage. Nat Neurosci. 2010;13(2):180-189.

149. Miller RH. Renegade nuclear enzymes disrupt axonal integrity. Nat Neurosci. 2010;13(2):143-144.

150. Beetz C, Brodhun M, Moutzouris K, et al. Identification of nuclear localisation sequences in spastin (SPG4) using a novel Tetra-GFP reporter system. Biochem Biophys Res Commun. 2004;318(4):1079-1084.

151. Rebane A, Aab A, Steitz JA. Transportins 1 and 2 are redundant nuclear import factors for hnRNP A1 and HuR. RNA. 2004;10(4):590-599.

152. Salinas S, Carazo-Salas RE, Proukakis C, Schiavo G, Warner TT. Spastin and microtubules: functions in health and disease. J Neurosci Res. 2007;85(12):2778-2782.

153. Lazeron RH, de Sonneville LM, Scheltens P, Polman CH, Barkhof F. Cognitive slowing in multiple sclerosis is strongly associated with brain volume reduction. Mult Scler. 2006;12(6):760-768.

154. Lazeron RH, Boringa JB, Schouten M, et al. Brain atrophy and lesion load as explaining parameters for cognitive impairment in multiple sclerosis. Mult Scler. 2005;11(5):524-531.
Degenerative Neurological and Neuromuscular Disease

\section{Publish your work in this journal}

Degenerative Neurological and Neuromuscular Disease is an international, peer-reviewed, open access journal focusing on research into degenerative neurological and neuromuscular disease, identification of therapeutic targets and the optimal use of preventative and integrated treatment interventions to achieve improved outcomes, enhanced

\section{Dovepress}

survival and quality of life for the patient. The manuscript management system is completely online and includes a very quick and fair peer-review system. Visit http://www.dovepress.com/testimonials.php to read real quotes from published authors. 